\title{
(6) OPEN ACCESS \\ Sickle cell disease: a neglected chronic disease of increasing global health importance
}

\author{
Subarna Chakravorty, ${ }^{1}$ Thomas N Williams ${ }^{1,2}$
}

${ }^{1}$ Department of Medicine, Imperial College, London, UK ${ }^{2}$ KEMRI-Wellcome Trust Research Programme, Kilifi, Kenya

\section{Correspondence to} Thomas N Williams, KEMRI-Wellcome Trust Research Programme, PO Box 230 Kilifi 80108, Kenya;

tom.williams@imperial.ac.uk

Received 8 June 2014 Revised 26 August 2014 Accepted 30 August 2014 Published Online First 19 September 2014

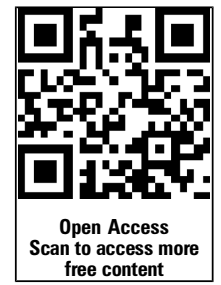

\section{CrossMark}

To cite: Chakravorty $S$ Williams TN. Arch Dis Child 2015;100:48-53.

\section{ABSTRACT}

Sickle cell disease (SCD) is a single gene disorder causing a debilitating systemic syndrome characterised by chronic anaemia, acute painful episodes, organ infarction and chronic organ damage and by a significant reduction in life expectancy. The origin of SCD lies in the malarial regions of the tropics where carriers are protected against death from malaria and hence enjoy an evolutionary advantage. More recently, population migration has meant that SCD now has a worldwide distribution and that a substantial number of children are born with the condition in higher-income areas, including large parts of Europe and North and South America. Newborn screening, systematic clinical followup and prevention of sepsis and organ damage have led to an increased life expectancy among people with SCD in many such countries; however, in resource-limited settings where the majority continue to be born, most affected children continue to die in early childhood, usually undiagnosed, due to the lack of effective programmes for its early detection and treatment. As new therapies emerge, potentially leading to disease amelioration or cure, it is of paramount importance that the significant burden of SCD in resource-poor countries is properly recognised.

\section{INTRODUCTION}

Sickle haemoglobin $(\mathrm{HbS})$ is a structural variant of normal adult haemoglobin ( $\mathrm{HbA}$ ) caused by a mutation in the $H B B$ gene that leads to the substitution of valine for glutamic acid at position 6 of the $\beta$-globin subunit $\left(\beta^{S}\right)$ of the haemoglobin molecule. ${ }^{1}$ The term 'sickle cell disease' (SCD) refers to any condition in which the production of $\mathrm{HbS}$ leads to pathophysiological consequences. The most common form $(>70 \% \text { of SCD worldwide })^{2}$ results from the homozygous inheritance of the $\beta^{S}$-mutation and is usually referred to as either 'SCD SS' or as 'sickle cell anaemia' (SCA). However, SCD can also result from the inheritance of $\beta^{S}$ in combination with a wide range of other $H B B$ mutations, the two most common being a second structural $\beta$-globin variant $\beta^{\mathrm{C}}$ (SCD SC) $^{3}$ and one of the many $\beta$-thalassaemia mutations that lead to the reduced production of normal $\beta$-globin (SCD S/ $\beta$-thalassaemia). ${ }^{4}$ SCD SS is the most severe form of SCD and, consequently, is the main focus of the current review.

\section{HISTORICAL PERSPECTIVE}

SCD was first described in the Western medical literature by the American physician James Herrick who reported the presence of 'peculiar elongated and sickle-shaped red blood corpuscles' in the blood film of a Grenadan student with a history of leg ulcers, shortness of breath and jaundice. ${ }^{5}$ Pauling and Itano ${ }^{6}$ established the fact that SCD was a molecular disease almost 50 years later while in the decades that followed, scientific advances led to descriptions of the structure of the $\mathrm{HbS}$ molecule, ${ }^{7}$ molecular basis of the sickling phenomenon, ${ }^{1}$ cloning and sequencing of the $\beta$-globin gene, development of molecular diagnostic methods ${ }^{8}$ and establishment of prenatal diagnosis. ${ }^{9}$

In parallel with such advances, significant progress was made towards improving clinical outcomes among those born with SCD during the 1970s and 1980s, before which very few affected subjects survived beyond 10 years. ${ }^{10}$ In response to reports of poor funding for SCD research, a series of comprehensive SCD centres were created in the USA during the $1970 \mathrm{~s},{ }^{11}$ and by 1994 the median age of death had risen to 48 and 42 years in women and men, respectively. ${ }^{12}{ }^{13}$ Following the introduction of newborn screening programmes in cohorts in the USA, ${ }^{14}$ Jamaica $^{15}$ and the UK, ${ }^{16}$ and the gradual introduction of a broad range of lifesaving measures (including penicillin prophylaxis, vaccination for common bacterial diseases, training of parents to detect splenic sequestration events and provision of disease-modifying treatment with hydroxycarbamide), in the US cohort overall survival to 18 years had risen to $85 \%$ by $2004^{14}$ and to $96 \%$ by $2010,{ }^{17}$ while in the London cohort overall survival to 16 years was almost universal by 2007. ${ }^{16}$ Nevertheless, despite these dramatic improvements, the outcome for adolescents and adults with SCD remains disappointing. In a recent US study, mortality among patients aged 20-25 years was twice that of patients aged 15-19 years, highlighting the importance of the transition from paediatric to adult services. ${ }^{18}$

\section{THE BURDEN AND GLOBAL DISTRIBUTION OF SCD}

The $\beta^{\mathrm{S}}$-mutation is the archetypal example of natural selection in humans. Heterozygotes, whose red blood cells contain both $\mathrm{HbA}$ and $\mathrm{HbS}$, are so strongly protected from malaria ${ }^{19}{ }^{20}$ that the global distribution and the frequency of the $\beta^{\mathrm{S}}$-mutation a mutation now strongly reflects the historic incidence of death from malaria. ${ }^{21}$ Nevertheless, despite the extraordinary protection that $\beta^{S}$-carriers enjoy from malaria, there are few places where the carrier frequencies exceed 25\% because the rise of the mutation in populations above that level has been kept in check by the profound disadvantage conferred by homozygosity. ${ }^{22}$ Despite the fact that SCD originates in the malaria-endemic world, population migration during the last few hundreds of years, first through the slave trade and more recently for economic and work-related reasons, 
means that substantial numbers of children with SCD are now being born in high-income countries, particularly in the larger cities in Europe and North America. ${ }^{23}$ No global data regarding the precise numbers of children born with SCD exist because, in contrast to Europe and North America, newborn screening for SCD is not available in most resource-poor countries with the highest predicted burdens; however, on the basis of data on carrier frequencies and global birth rates, we recently estimated that around 312000 children are born each year with SCD SS, a figure that includes approximately 300 births in the UK and almost 3000 in the USA. ${ }^{24}$ Given the more limited availability of detailed contemporary allele frequency data for haemoglobin $\mathrm{C}(\mathrm{HbC})$ and the $\beta$-thalassaemias, it is more difficult to estimate the numbers born with other forms of SCD, but they probably total a further $50000-100000$ births per year. $^{2}$

Despite the numbers born with SCD in resource-poor countries, remarkably, few detailed studies have described the clinical course and complications of the disease in that context. Even today, the majority of those born with the disease in Africa, where more than $80 \%$ of affected births occur, die undiagnosed in early childhood, ${ }^{22}$ presumably from preventable causes that include invasive bacterial diseases, ${ }^{25}$ malaria $^{26}$ and severe acute anaemia. As a consequence, in many parts of sub-Saharan Africa, SCD is probably responsible for up to $6 \%$ of all child deaths, ${ }^{2} 27$ a situation that must be addressed if recent improvements in overall child survival are to be consolidated. Because so little is known about the clinical course and natural history of SCD in resource-poor countries, the majority of this review is focused on data from Europe and North America, where most detailed studies have been conducted.

\section{DIAGNOSIS AND PATHOPHYSIOLOGY}

The diagnosis of SCD relies on the analysis of haemoglobin, most commonly using either protein electrophoresis or highperformance liquid chromatography. Subjects with the most common form of SCD, SCD SS, produce no HbA, but predominantly produce $\mathrm{HbS}$ along with variable amounts of haemoglobin $\mathrm{F}(\mathrm{HbF})$ and haemoglobin $\mathrm{A}_{2}\left(\mathrm{HbA}_{2}\right)$, while those with SCD $\mathrm{SC}$ produce mainly $\mathrm{HbS}$ and $\mathrm{HbC}$. DNA-based methods are commonly used to confirm the diagnosis of SCD in more complicated cases. $^{28}$

Since SCD was first described a century ago, a great deal has been learnt about its pathophysiological consequences. Under conditions of hypoxia, acidity and cellular dehydration, the polymerisation of $\mathrm{HbS}$ within erythrocytes leads to their deformation into the characteristic 'sickle' shape. In dynamic interaction with the vascular endothelium, this sickling leads to episodic microvascular occlusion, ischaemia and reperfusion, ${ }^{29}$ vascular and inflammatory stress, and increased expression of vascular oxidases, inflammatory cytokines and adhesion molecules. $^{29}$ In addition, chronic haemolysis results in anaemia, hypoxia, cholelithiasis, fatigue, exercise intolerability, hypercoagulability $^{30}$ and vasculopathy, ${ }^{31}$ which lead in turn to endothelial nitric oxide depletion, development of pulmonary hypertension $^{32}$ and ischaemic strokes. ${ }^{33}$ Recent work in transgenic sickle mice has highlighted the central role played by hypoxia in generating multi-organ damage by increased adenosine signalling via the G-protein coupled adenosine receptor ADORA2B. ${ }^{34}$

The pathophysiology of pain in SCD remains poorly understood. ${ }^{35}$ Nociceptive stimuli generated from cellular responses to vaso-occlusion, tissue infarction, inflammation and ischaemia-reperfusion injury activate receptors in the peripheral sensory nerves. However, neuropathic pain and increased sensitisation to mechanical touch have also been frequently noted, the latter being recently characterised as driven by increased primary afferent input to the central nervous system by the transient receptor potential vanilloid-1 channel in transgenic sickle mice. ${ }^{36}$

\section{CLINICAL FEATURES}

The clinical features of SCD, described through multiple studies conducted in high-income populations in Europe and North America, are defined by chronic anaemia, sepsis, haemolysis and recurrent acute vaso-occlusive crises. The last are characterised by pain and a systemic inflammatory response that may be severe, episodic and unpredictable. Some of the more common acute clinical and laboratory features of SCD are summarised in table 1, along with descriptions of current approaches to their management. Although this list would almost certainly look very different among children with SCD in low-income countries who are often exposed to malaria, geo-helminth infections, undernutrition and variable standards of care, this is beyond the scope of the current review.

\section{VASO-OCCLUSIVE CRISES AND BONE DISEASE}

Painful vaso-occlusive crisis due to bony infarction is the commonest cause for hospital admissions. Infants may present with dactylitis or bony infarction of digits, irritability and swelling of fingers or toes. Infarction can affect any bone or joint and may mimic osteomyelitis. ${ }^{37}$ Avascular necrosis-the result of recurrent vaso-occlusion and infarction of the articular surfaces and heads of long bones-is found in 12\%-15\% of children with $\mathrm{SCA}^{38} 39$ and has been associated with both high haematocrit and the concomitant presence of $\alpha$-thalassaemia. ${ }^{40}{ }^{41}$ Osteomyelitis and septic arthritis, most commonly due to Salmonella spp, Staphylococcus aureus and Gram negative enteric bacilli, ${ }^{42}$ are also common, a cumulative incidence of $12 \%$ having been reported in one paediatric cohort in metropolitan France. ${ }^{43}$ Osteopaenia and osteoporosis are frequent findings in SCD and patients may suffer from chronic back pain as a result of vertebral collapse. ${ }^{38}$

\section{ACUTE CHEST SYNDROME}

Acute chest syndrome (ACS) is the second most common cause of hospitalisation and is characterised by intrapulmonary ischaemia and infarction, systemic hypoxia and pulmonary infiltrates on chest radiography. ${ }^{44}$ Community-acquired pneumonias and fat embolism from bone marrow necrosis have been implicated in its pathogenesis. In a recent study, $50 \%$ of paediatric and adolescent patients with SCD reported acute pulmonary events during a median follow-up of 21 months. Children with asthma, a major cause of morbidity in SCD, suffer twice as many episodes of ACS as those without ${ }^{45}$ while other risk factors include a high white cell count, and a high tricuspidregurgitant jet velocity (TRV). ${ }^{46}$ While raised TRVs have been associated with mortality in adults, ${ }^{32}$ no such correlation has been reported in children; nevertheless, in one recent study, a gradual decline in exercise tolerance was noted in follow-up of children with elevated TRVs, suggesting that tricuspid valve disease may well progress throughout childhood. ${ }^{47}$

\section{BACTERIAL SEPSIS}

Evidence of reduced splenic function is evident from early childhood. Functional asplenia is the norm by 6 months to 3 years of age 48 and leads to an increased susceptibility to infections, particularly those caused by encapsulated bacteria and malaria. ${ }^{25265051}$ In high-income countries, mortality from 
sepsis was greatly reduced following the introduction of newborn screening and the early implementation of penicillin prophylaxis, while further improvements in survival and reductions in documented blood stream infections were subsequently achieved following the introduction of Haemophilus influenzae and Streptococcus pneumoniae vaccines. ${ }^{17}$ Nevertheless, the combination of suboptimal compliance and resistance to penicillin prophylaxis, non-vaccine serotypes of $S$. pneumoniae, and hyposplenism means that even today children with SCD remain at increased risk of bacterial infections. ${ }^{52}$

\section{SEQUESTRATION CRISES}

Splenic sequestration is defined as an acute enlargement of the spleen with a drop in haemoglobin of at least $2 \mathrm{~g} / \mathrm{dL}$ from baseline and a normal or raised reticulocyte count. ${ }^{53}$ In severe cases, it may result in hypovolemic shock and death in a matter of hours. Splenic sequestration can occur as early as 3 months of age but is rarely seen beyond the age of 6 years. Recurrence can occur in up to $50 \%$ of children. ${ }^{54}$ Prompt transfusion can be life saving. ${ }^{55}$ Hepatic sequestration is a rare but severe complication of SCD caused by the obstruction of hepatic sinusoidal blood flow by sickled erythrocytes and is characterised by painful hepatomegaly, anaemia and reticulocytosis. ${ }^{56}$ Treatment is supportive, with fluids and analgesia along with early red cell exchange transfusions. ${ }^{57}$

\section{ISCHAEMIC STROKES AND SILENT INFARCTS}

SCD confers a higher risk of childhood stroke than any other paediatric disease. In all, $11 \%$ of patients with SCD develop an overt stroke by the age of 20 years, increasing to $24 \%$ by the age of 45 years. The risk of first stroke is highest in the first decade of life, being $1.02 \%$ per year between 2 and 5 years. ${ }^{58}$ Two-thirds of children with a history of stroke will develop a second stroke within the first 2-3 years of an initial event. ${ }^{59}$ The risk of stroke can be determined by measuring blood velocities in the middle cerebral and internal carotid arteries by transcranial Doppler (TCD) ultrasonography. In the Stroke Prevention in Sickle Cell Anaemia (STOP) trial, the risk of stroke among children with high TCD velocities was reduced by $90 \%$ by maintaining $\mathrm{HbS}$ concentrations at $<30 \%$ through regular blood transfusions. ${ }^{60}$ Children developed further strokes when transfusion therapy was stopped ${ }^{61}$ or treatment was switched to hydroxycarbamide, ${ }^{62}$ highlighting the need for lifelong transfusion in this patient group. Silent cerebral infarcts (SCIs) on MRI scanning are common in asymptomatic patients with SCD and are associated with neurocognitive impairment, reduced academic achievement and stroke progression. Regular blood transfusion in children with SCI has recently been shown to reduce the incidence of $\mathrm{SCI}^{63}$ and monitoring for worsening intellectual abilities is important. ${ }^{64}$

\section{GIRDLE SYNDROME AND PRIAPISM}

Severe abdominal pain, often unresponsive to analgesia and associated with intestinal ileus and acute ischaemic colitis, is termed 'girdle syndrome' owing to the circumferential distribution of pain. A high index of suspicion and early implementation of supportive therapy (including emergency red cell exchange transfusion, analgesia and fluids) may prevent irreversible ischaemic damage to the gut. ${ }^{65}$ Priapism, defined as prolonged penile erection lasting $>4 \mathrm{~h}$, is a urological emergency and can result in fibrosis of the corpora cavernosa and permanent erectile dysfunction if not treated early. SCD is the commonest cause of priapism in children and is thought to be caused by chronic nitric oxide depletion within the penile vasculature due to chronic intravascular haemolysis, aberrant G-protein signalling, smooth muscle hypoxia, acidosis and impaired smooth muscle contraction. ${ }^{66}$ Early intervention in the form of red cell exchange transfusion and surgical decompression of the corpora is essential. Recurrent, 'stuttering' priapism may be treated by hydroxycarbamide, chronic red cell exchange transfusions or sildenafil. $^{67}$

\section{STANDARDS OF TREATMENT}

Universal or targeted newborn screening programmes, implementation of simple treatments such as vaccination and antibiotic prophylaxis, regular follow-up in specialist clinics and improved parental education have together led to major reductions in the early mortality from SCD in high- and middle-income countries. For example, simply teaching parents how to palpate their children's spleens led to a $90 \%$ reduction in mortality from splenic sequestration crises in Jamaica. ${ }^{55}$ Nevertheless, despite such encouraging advances, the overall outcome of patients with SCD remains poor. The recent UK National Confidential Enquiry into Patient Outcome and Death for haemoglobinopathies ${ }^{68}$ revealed a significant inequity of specialist care in the country and the lack of adequate knowledge of haemoglobinopathies within the medical community, and recommended the establishment of a national database to capture information regarding prevalence, therapy and adverse events of SCD.

A programme of universal screening for SCD was implemented in England in 2001 and was subsequently rolled out to Scotland and Wales ${ }^{28}$ through which approximately 300 births and 17000 carriers are detected each year. ${ }^{69}$ The UK National Standards for the Treatment of SCD in Children ${ }^{70}$ highlights the need for coordinating care between the screening service, primary care and local and specialist haemoglobinopathy teams, and mandates the prescription of penicillin to children by 6 months of age along with additional polysaccharide antigen vaccination for $S$. pneumoniae, and the provision of annual TCD monitoring to children over 2 years.

Adequate and prompt management of the acute complications of SCD remains the mainstay of clinical care. While the treatments of common complications are summarised in table 1, pain relief, hydration, aggressive treatment of sepsis and blood transfusions remain central to acute management.

\section{SPECIFIC THERAPIES FOR SCD} Hydroxycarbamide

Hydroxycarbamide (or hydroxyurea) remains the only agent that has been proven to reduce the number of episodes of painful crises, ACS and hospitalisations in randomised control trials in adults, ${ }^{71}$ school-age children ${ }^{72}$ and infants ${ }^{73}$ with SCD. Despite its well known beneficial effects and excellent long-term toxicity profile, ${ }^{74}$ utilisation remains suboptimal due to userand prescriber-related uncertainties regarding toxicities, monitoring and efficacy. ${ }^{75}$

\section{Blood transfusion}

A number of observational and randomised controlled trials have established the pivotal role of transfusion therapy in the management of SCD, most notably in primary stroke prevention $^{60} 61$ and through improved oxygenation in ACS. ${ }^{76}$ Secondary analysis of two large paediatric randomised control trials, namely, the Stroke Prevention (STOP) and Stoke With Transfusions Changing to Hydroxyurea (SWiTCH) trials, indicated that transfusion therapy was more effective in reducing the incidence of painful crises and ACS than either standard 
Table 1 Common clinical presentations of SCD

\begin{tabular}{|c|c|c|c|}
\hline $\begin{array}{l}\text { Clinical } \\
\text { presentation }\end{array}$ & Symptoms & Laboratory findings & Treatment \\
\hline Painful crisis & Pain, localised swelling, fever & $\begin{array}{l}\text { Low Hb, high reticulocyte count, high } \\
\text { LDH, high bilirubin, high CRP }\end{array}$ & $\begin{array}{l}\text { Hydration } \\
\text { Analgesia } \\
\text { Antibiotics }\end{array}$ \\
\hline $\begin{array}{l}\text { Acute chest } \\
\text { syndrome }\end{array}$ & $\begin{array}{l}\text { Chest pain, fever, hypoxia, cough; may } \\
\text { progress from painful crisis elsewhere }\end{array}$ & $\begin{array}{l}\text { Low } \mathrm{Hb} \text {, high reticulocyte count, high } \\
\mathrm{LDH} \text {, pulmonary infiltrates on CXR }\end{array}$ & Respiratory support, antibiotics, red cell exchange transfusion \\
\hline Bacterial sepsis & Pain, localised swelling, fever & $\begin{array}{l}\text { Low } \mathrm{Hb} \text {, high reticulocyte count, high } \\
\mathrm{LDH} \text {, high CRP, positive cultures }\end{array}$ & $\begin{array}{l}\text { Hydration } \\
\text { Analgesia } \\
\text { Antibiotics }\end{array}$ \\
\hline $\begin{array}{l}\text { Sequestration } \\
\text { crisis }\end{array}$ & $\begin{array}{l}\text { Pain, severe pallor, hepatomegaly or } \\
\text { splenomegaly }\end{array}$ & Low $\mathrm{Hb}$, high reticulocyte count & Urgent red cell transfusion, pain relief \\
\hline Aplastic crisis & Pallor & $\begin{array}{l}\text { Low } \mathrm{Hb} \text {, low reticulocyte count, } \\
\text { parvovirus } \mathrm{B} 19 \text { +ve }\end{array}$ & Urgent red cell transfusion \\
\hline $\begin{array}{l}\text { Acute ischaemic } \\
\text { stroke }\end{array}$ & $\begin{array}{l}\text { Hemiplegia, altered consciousness, } \\
\text { seizures }\end{array}$ & MRI brain with characteristic findings & $\begin{array}{l}\text { Urgent red cell exchange transfusion aim to reduce } \mathrm{HbS} \text { to } \\
<30 \%\end{array}$ \\
\hline Girdle syndrome & $\begin{array}{l}\text { Abdominal pain and distension, reduced } \\
\text { or absent bowel sounds, pallor, fever }\end{array}$ & $\begin{array}{l}\text { AXR may show dilated bowel loops. Low } \\
\mathrm{Hb} \text {, high reticulocyte count, high CRP }\end{array}$ & $\begin{array}{l}\text { Nil by mouth, NG tube on free drainage, broad spectrum } \\
\text { antibiotics with anaerobic cover, red cell exchange transfusion, } \\
\text { surgical review }\end{array}$ \\
\hline Priapism & Painful, persistent erection & & $\begin{array}{l}\text { Hydration, pain relief, urgent urology review and intervention: } \\
\text { red cell exchange transfusion }\end{array}$ \\
\hline
\end{tabular}

supportive care or hydroxycarbamide. ${ }^{77} 78$ Nevertheless, despite its well-recognised benefits, chronic transfusion therapy can result in iron overload (leading to organ damage and requiring additional iron chelation therapy), alloimmunsation, transfusion-acquired infections, venous access-related issues such as thrombosis and line-related sepsis and loss of work and schooling. ${ }^{79}$ Coupled with the fact that the total economic costs of chronic transfusion therapy far exceeds those of hydroxycarbamide treatment, ${ }^{80} 81$ transfusion therapy is mainly reserved for specific indications such as stroke risk reduction, renal failure or recurrent painful crises that are less responsive to treatment with hydroxycarbamide.

\section{Allogeneic HSCT and gene therapy}

Allogeneic haemopoietic stem cell transplant (HSCT) is the only curative treatment for SCD and is successful in $85 \%-90 \%$ of patients. ${ }^{82}$ Transplantation offers disease-free survival and stabilisation of neurological lesions. Nevertheless, the fine balance between the benefits and risks of treatment, including long-term toxicities such as infertility and endocrinopathies, ${ }^{83}$ the variable and unpredictable severity of SCD and the low availability of specialist services mean that HSCT is generally reserved for the most seriously affected patients. Table 2 outlines current indications for HSCT in SCD in the UK. Gene therapy has been in development for a number of years and aims to abrogate SCD-related symptoms by manipulation of haemopoietic stem cells, either by viral vector-mediated insertion of a functional $\beta$ globin gene or by various gene-editing techniques that reduce intracellular sickling by enhanced production of HbF. Phase I studies of gene therapy have recently begun in several centres in the USA and Europe. ${ }^{84} 85$

\section{FUTURE PERSPECTIVES}

In the short term, refining the indications for access to known effective treatments is a major priority; for example, the accumulated data on hydroxycarbamide suggest that the benefits of the drug outweigh the risks in the vast majority of patients and that access to hydroxycarbamide therapy should be available to all who want it. At the same time, new therapies targeting specific mechanisms of $\mathrm{HbF}$ induction, endothelial dysfunction, pain management, organ damage and gene therapy are under intense research scrutiny. ${ }^{86}$ Nevertheless, improving the profile of SCD as a major health problem in Africa and India, including the introduction of newborn screening programmes and the improved provision of even the most basic of medical care, will benefit the greatest number of patients with SCD worldwide. A good starting point would be the collection of more detailed and up-to-date data regarding the expected birth frequencies

Table 2 HSCT indications in SCD (ebmt.org/Contents/Resources/Library/EBMTESHhandbook)

\begin{tabular}{ll}
\hline One of: & Neurological deficit due to stroke or subarachnoid haemorrhage \\
& Recurrent acute chest syndrome not responding to 6-month course of hydroxycarbamide \\
& Recurrent vaso-occlusive crises not responding to 6-month course of hydroxycarbamide \\
AND & $<16$ years \\
AND & HLA-identical matched related donor available \\
Candidates who may be considered for HSCT in special circumstances: & Problems relating to future medical care e.g. unavailability of adequately screened blood products \\
& SCD relapsing after previous HSCT \\
& - Transfusion-dependent S/ $\beta^{0}$ thalassaemia \\
\end{tabular}

HLA, human leukocyte antigen; HSCT, haemopoietic stem cell transplant; SCD, sickle cell disease. 
and outcomes of SCD in these regions at scales that will be meaningful to health planners responsible for making such decisions, while estimates of the economic costs and benefits of improved care are also needed. Such data will be most influential if the end-users are involved from the outset. At the same time, improved advocacy for SCD is needed at every level including increased education about SCD in schools and colleges in affected communities, increased involvement of patientsupport groups and influential groups such as celebrities, politicians, funders and health agencies internationally. Finally, the development of cheap, reliable point of care methods for the diagnosis of SCD, akin to those developed for other diseases of poverty such as HIV and malaria, could be transformative at many different levels. Translation of research findings to clinical practice in improving patient outcomes worldwide remains the greatest challenge.

Acknowledgements TNW is supported through a Senior Research Fellowship (091758) from the Wellcome Trust, UK

Competing interests None.

Provenance and peer review Commissioned; externally peer reviewed.

Open Access This is an Open Access article distributed in accordance with the terms of the Creative Commons Attribution (CC BY 4.0) license, which permits others to distribute, remix, adapt and build upon this work, for commercial use, provided the original work is properly cited. See: http://creativecommons.org/licenses/ by/4.0/

\section{REFERENCES}

1 Murayama M. Structure of sickle cell hemoglobin and molecular mechanism of the sickling phenomenon. Clin Chem 1967;13:578-88.

2 Modell B, Darlison M. Global epidemiology of haemoglobin disorders and derived service indicators. Bull World Health Organ 2008;86:480-7.

3 Nagel RL, Fabry ME, Steinberg MH. The paradox of hemoglobin SC disease. Blood Rev 2003;17:167-78.

4 Serjeant GR, Serjeant BE, Fraser RA, et al. Hb S-beta-thalassemia: molecular, hematological and clinical comparisons. Hemoglobin 2011;35:1-12.

5 Herrick JB. Peculiar elongated and sickle-shaped red blood corpuscles in a case of severe anemia. 1910. Yale J Biol Med 2001;74:179-84.

6 Pauling L, Itano HA, Singer SJ, et al. Sickle cell anemia a molecular disease. Science 1949:110:543-8.

7 Ingram VM. A specific chemical difference between the globins of normal human and sickle-cell anaemia haemoglobin. Nature 1956;178:792-4.

8 Conner BJ, Reyes AA, Morin C, et al. Detection of sickle cell beta S-globin allele by hybridization with synthetic oligonucleotides. Proc Natl Acad Sci USA 1983;80:278-82

9 Kan YW, Dozy AM, Alter BP, et al. Detection of the sickle gene in the human fetus. Potential for intrauterine diagnosis of sickle-cell anemia. $N$ Engl J Med $1972 \cdot 287: 1-5$

10 JV D. The haemolytic anaemias- congential and acquired. New York: Grune and Stratton, 1960

11 Scott RB. Health care priority and sickle cell anemia. JAMA 1970;214:731-4.

12 Platt OS, Brambilla DJ, Rosse WF, et al. Mortality in sickle cell disease. Life expectancy and risk factors for early death. N Engl J Med 1994;330:1639-44.

13 Leikin SL, Gallagher D, Kinney TR, et al. Mortality in children and adolescents with sickle cell disease. Cooperative Study of Sickle Cell Disease. Pediatrics 1989;84:500-8.

14 Quinn CT, Rogers ZR, Buchanan GR. Survival of children with sickle cell disease. Blood 2004;103:4023-7.

15 Wierenga KJ, Hambleton IR, Lewis NA. Survival estimates for patients with homozygous sickle-cell disease in Jamaica: a clinic-based population study. Lancet 2001;357:680-3

16 Telfer $\mathrm{P}$, Coen $\mathrm{P}$, Chakravorty $\mathrm{S}$, et al. Clinical outcomes in children with sickle cell disease living in England: a neonatal cohort in East London. Haematologica 2007:92:905-12.

17 Quinn CT, Rogers ZR, McCavit TL, et al. Improved survival of children and adolescents with sickle cell disease. Blood 2010;115:3447-52.

18 Hamideh D, Alvarez O. Sickle Cell Disease Related Mortality in the United States (1999-2009). Pediatr Blood Cancer 2013;60:1482-6.

19 Allison AC. Protection afforded by sickle-cell trait against subtertian malareal infection. Br Med J 1954;1:290-4.

20 Taylor SM, Cerami C, Fairhurst RM. Hemoglobinopathies: slicing the Gordian knot of Plasmodium falciparum malaria pathogenesis. PLoS Pathog 2013;9:e1003327.
21 Piel FB, Patil AP, Howes RE, et al. Global distribution of the sickle cell gene and geographical confirmation of the malaria hypothesis. Nat Commun 2010;1:104.

22 Grosse SD, Odame I, Atrash HK, et al. Sickle cell disease in Africa: a neglected cause of early childhood mortality. Am J Prev Med 2011:41:S398-405.

23 Piel FB, Tatem AJ, Huang Z, et al. Global migration and the changing distribution of sickle haemoglobin: a quantitative study of temporal trends between 1960 and 2000. Lancet Glob Health 2014;2:e80-9

24 Piel FB, Patil AP, Howes RE, et al. Global epidemiology of sickle haemoglobin in neonates: a contemporary geostatistical model-based map and population estimates. Lancet 2013:381:142-51.

25 Williams TN, Uyoga S, Macharia A, et al. Bacteraemia in Kenyan children with sickle-cell anaemia: a retrospective cohort and case-control study. Lancet 2009:374:1364-70.

26 McAuley CF, Webb C, Makani J, et al. High mortality from Plasmodium falciparum malaria in children living with sickle cell anemia on the coast of Kenya. Blood 2010;116:1663-8.

27 Ndila C, Bauni E, Nyirongo V, et al. Verbal autopsy as a tool for identifying children dying of sickle cell disease: a validation study conducted in Kilifi district, Kenya. BMC Med 2014;12:65

28 Ryan K, Bain BJ, Worthington D, et al. Significant haemoglobinopathies: guidelines for screening and diagnosis. Br J Haematol 2010;149:35-49.

29 Rees DC, Williams TN, Gladwin MT. Sickle-cell disease. Lancet 2010;376:2018-31.

30 Ataga $\mathrm{KI}$, Moore CG, Hillery CA, et al. Coagulation activation and inflammation in sickle cell disease-associated pulmonary hypertension. Haematologica 2008;93:20-6.

31 Kato GJ, McGowan V, Machado RF, et al. Lactate dehydrogenase as a biomarker of hemolysis-associated nitric oxide resistance, priapism, leg ulceration, pulmonary hypertension, and death in patients with sickle cell disease. Blood 2006;107:2279-85

32 Gladwin MT, Sachdev V, Jison ML, et al. Pulmonary hypertension as a risk factor for death in patients with sickle cell disease. N Engl J Med 2004;350:886-95.

33 Kato GJ, Hsieh M, Machado R, et al. Cerebrovascular disease associated with sickle cell pulmonary hypertension. Am J Hematol 2006;81:503-10.

34 Sun K, Xia Y. New insights into sickle cell disease: a disease of hypoxia. Curr Opin Hematol 2013;20:215-21

35 Ballas SK, Gupta K, Adams-Graves P. Sickle cell pain: a critical reappraisal. Blood 2012;120:3647-56.

36 Hillery CA, Kerstein PC, Vilceanu D, et al. Transient receptor potential vanilloid 1 mediates pain in mice with severe sickle cell disease. Blood 2011;118:3376-83.

37 Berger $E$, Saunders N, Wang $L$, et al. Sickle cell disease in children: differentiating osteomyelitis from vaso-occlusive crisis. Arch Pediatr Adolesc Med 2009;163: 251-5.

38 Almeida A, Roberts I. Bone involvement in sickle cell disease. $\mathrm{Br} J$ Haematol 2005;129:482-90.

39 Mahadeo KM, Oyeku S, Taragin B, et al. Increased prevalence of osteonecrosis of the femoral head in children and adolescents with sickle-cell disease. Am J Hematol 2011;86:806-8

40 Milner PF, Kraus AP, Sebes Jl, et al. Sickle cell disease as a cause of osteonecrosis of the femoral head. N Engl J Med 1991;325:1476-81.

41 Adekile AD, Gupta R, Yacoub F, et al. Avascular necrosis of the hip in children with sickle cell disease and high $\mathrm{Hb} \mathrm{F}$ : magnetic resonance imaging findings and influence of alpha-thalassemia trait. Acta Haematol 2001;105:27-31.

42 Burnett MW, Bass JW, Cook BA. Etiology of osteomyelitis complicating sickle cell disease. Pediatrics 1998;101:296-7.

43 Neonato MG, Guilloud-Bataille M, Beauvais P, et al. Acute clinical events in 299 homozygous sickle cell patients living in France. French Study Group on Sickle Cell Disease. Eur J Haematol 2000;65:155-64.

44 Miller AC, Gladwin MT. Pulmonary complications of sickle cell disease. Am J Respir Crit Care Med 2012;185:1154-65.

45 Boyd JH, Macklin EA, Strunk RC, et al. Asthma is associated with acute chest syndrome and pain in children with sickle cell anemia. Blood 2006;108:2923-7.

46 Paul R, Minniti CP, Nouraie M, et al. Clinical correlates of acute pulmonary events in children and adolescents with sickle cell disease. Eur J Haematol 2013:91:62-8.

47 Gordeuk VR, Minniti CP, Nouraie M, et al. Elevated tricuspid regurgitation velocity and decline in exercise capacity over 22 months of follow up in children and adolescents with sickle cell anemia. Haematologica 2011;96:33-40.

48 Pearson HA, Spencer RP, Cornelius EA. Functional asplenia in sickle-cell anemia. N Engl J Med 1969;281:923-6.

49 William BM, Thawani N, Sae-Tia S, et al. Hyposplenism: a comprehensive review. Part II: clinical manifestations, diagnosis, and management. Hematology 2007:12:89-98

50 Luzzatto L. Sickle cell anaemia and malaria. Mediterr J Hematol Infect Dis 2012;4 e2012065

51 Booth C, Inusa B, Obaro SK. Infection in sickle cell disease: a review. Int J Infect Dis 2010;14:e2-12.

52 Ellison $\mathrm{AM}$, Ota KV, McGowan KL, et al. Epidemiology of Bloodstream Infections in Children with Sickle Cell Disease. Pediatr Infect Dis J 2013;32:560-3. 
53 Topley JM, Rogers DW, Stevens MC, et al. Acute splenic sequestration and hypersplenism in the first five years in homozygous sickle cell disease. Arch Dis Child 1981;56:765-9.

54 Brousse $V$, Buffet $P$, Rees D. The spleen and sickle cell disease: the sick(led) spleen. Br J Haematol 2014;166:165-76.

55 Emond AM, Collis R, Darvill D, et al. Acute splenic sequestration in homozygous sickle cell disease: natural history and management. J Pediatr 1985;107:201-6.

56 Norris WE. Acute hepatic sequestration in sickle cell disease. J Natl Med Assoc 2004;96:1235-9.

57 Gardner K, Suddle A, Kane P, et al. How we treat sickle hepatopathy and liver transplantation in adults. Blood 2014;123:2302-7.

58 Ohene-Frempong K, Weiner SJ, Sleeper LA, et al. Cerebrovascular accidents in sickle cell disease: rates and risk factors. Blood 1998;91:288-94.

59 Musallam KM, Khoury RA, Abboud MR. Cerebral infarction in children with sickle cell disease: a concise overview. Hemoglobin 2011;35:618-24

60 Adams RJ, McKie VC, Hsu L, et al. Prevention of a first stroke by transfusions in children with sickle cell anemia and abnormal results on transcranial Doppler ultrasonography. N Engl J Med 1998;339:5-11.

61 Adams RJ, Brambilla D, Optimizing Primary Stroke Prevention in Sickle Cell Anemia Trial I. Discontinuing prophylactic transfusions used to prevent stroke in sickle cell disease. N Engl J Med 2005;353:2769-78.

62 Ware RE, Helms RW, Investigators SW. Stroke With Transfusions Changing to Hydroxyurea (SWiTCH). Blood 2012;119:3925-32.

63 DeBaun MR, Gordon M, McKinstry RC, et al. Controlled trial of transfusions for silent cerebral infarcts in sickle cell anemia. N Engl J Med 2014;371:699-710.

64 DeBaun MR, Armstrong FD, McKinstry RC, et al. Silent cerebral infarcts: a review on a prevalent and progressive cause of neurologic injury in sickle cell anemia. Blood 2012;119:4587-96.

65 Qureshi A, Lang N, Bevan DH. Sickle cell 'girdle syndrome' progressing to ischaemic colitis and colonic perforation. Clin Lab Haematol 2006;28:60-2.

66 Donaldson JF, Rees RW, Steinbrecher HA. Priapism in children: a comprehensive review and clinical guideline. J Pediatr Urol 2014;10:11-24.

67 Burnett AL, Anele UA, Trueheart IN, et al. Randomized controlled trial of sildenafil for preventing recurrent ischemic priapism in sickle cell disease. Am J Med 2014;127:664-8.

68 Lucas SB, Mason DG. A Sickle Crisis? In: Mason M, ed. UK: National Confidential Enquiry into Patient Outcome and Death, 2008.

69 Streetly A, Latinovic R, Hall K, et al. Implementation of universal newborn bloodspot screening for sickle cell disease and other clinically significant haemoglobinopathies in England: screening results for 2005-7. J Clin Pathol 2009;62:26-30.

70 Dick M. Sickle cell disease in childhood—standards and guidelines for clinical care, 2010. http://sct.screening.nhs.uk/standardsandguidelines
71 Charache S, Terrin ML, Moore RD, et al. Effect of hydroxyurea on the frequency of painful crises in sickle cell anemia. Investigators of the Multicenter Study of Hydroxyurea in Sickle Cell Anemia. N Engl J Med 1995;332:1317-22.

72 Kinney TR, Helms RW, O'Branski EE, et al. Safety of hydroxyurea in children with sickle cell anemia: results of the HUG-KIDS study, a phase I/II trial. Pediatric Hydroxyurea Group. Blood 1999;94:1550-4.

73 Wang WC, Ware RE, Miller ST, et al. Hydroxycarbamide in very young children with sickle-cell anaemia: a multicentre, randomised, controlled trial (BABY HUG). Lancet 2011;377:1663-72.

74 Steinberg MH, McCarthy WF, Castro 0, et al. The risks and benefits of long-term use of hydroxyurea in sickle cell anemia: a 17.5 year follow-up. Am J Hematol 2010:85:403-8.

75 Brandow $A M$, Jirovec DL, Panepinto JA. Hydroxyurea in children with sickle cell disease: practice patterns and barriers to utilization. Am J Hematol 2010;85:611-13.

76 Vichinsky EP, Neumayr LD, Earles AN, et al. Causes and outcomes of the acute chest syndrome in sickle cell disease. National Acute Chest Syndrome Study Group. N Engl J Med 2000;342:1855-65.

77 Miller ST, Wright E, Abboud M, et al. Impact of chronic transfusion on incidence of pain and acute chest syndrome during the Stroke Prevention Trial (STOP) in sickle-cell anemia. J Pediatr 2001;139:785-9.

78 Alvarez 0 , Yovetich NA, Scott JP, et al. Pain and other non-neurological adverse events in children with sickle cell anemia and previous stroke who received hydroxyurea and phlebotomy or chronic transfusions and chelation: results from the SWiTCH clinical trial. Am J Hematol 2013;88:932-8.

79 Chou ST. Transfusion therapy for sickle cell disease: a balancing act. Hematol Am Soc Hematol Educ Program 2013;2013:439-46.

80 Wayne AS, Schoenike SE, Pegelow CH. Financial analysis of chronic transfusion for stroke prevention in sickle cell disease. Blood 2000;96:2369-72.

81 Wang WC, Oyeku SO, Luo Z, et al. Hydroxyurea is associated with lower costs of care of young children with sickle cell anemia. Pediatrics 2013;132:677-83.

82 Locatelli F, Pagliara D. Allogeneic hematopoietic stem cell transplantation in children with sickle cell disease. Pediatr Blood Cancer 2012;59:372-6.

83 Dallas $\mathrm{MH}$, Triplett $\mathrm{B}$, Shook DR, et al. Long-term outcome and evaluation of organ function in pediatric patients undergoing haploidentical and matched related hematopoietic cell transplantation for sickle cell disease. Biol Blood Marrow Transplant 2013;19:820-30.

84 Dong A, Rivella S, Breda L. Gene therapy for hemoglobinopathies: progress and challenges. Trans/ Res 2013;161:293-306.

85 Chandrakasan S, Malik P. Gene therapy for hemoglobinopathies: the state of the field and the future. Hematol Oncol Clin North Am 2014;28:199-216.

86 Hoots WK, Shurin SB. Future directions of sickle cell disease research: the NIH perspective. Pediatr Blood Cancer 2012;59:353-7. 